Acta Crystallographica Section F

Structural Biology

and Crystallization

Communications

ISSN 1744-3091

\section{Crystallization and preliminary structure determination of the transfer protein TraM from the Gram-positive conjugative plasmid pIP501}

The major means of horizontal gene spread (e.g. of antibiotic resistance) is conjugative plasmid transfer. It presents a serious threat especially for hospitalized and immuno-suppressed patients, as it can lead to the accelerated spread of bacteria with multiple antibiotic resistances. Detailed information about the process is available only for bacteria of Gram-negative $(\mathrm{G}-)$ origin and little is known about the corresponding mechanisms in Gram-positive $(\mathrm{G}+)$ bacteria. Here we present the purification, biophysical characterization, crystallization and preliminary structure determination of the TraM C-terminal domain (TraM $\Delta$, comprising residues 190-322 of the full-length protein), a putative transfer protein from the $\mathrm{G}+$ conjugative model plasmid pIP501. The crystals diffracted to $2.5 \AA$ resolution and belonged to space group $P 1$, with unitcell parameters $a=39.21, b=54.98, c=93.47 \AA$ А $\alpha=89.91, \beta=86.44, \gamma=78.63^{\circ}$ and six molecules per asymmetric unit. The preliminary structure was solved by selenomethionine single-wavelength anomalous diffraction.

\section{Introduction}

Bacterial conjugation is the prevalent means in horizontal gene transfer, by which plasmid-encoded antibiotic resistance and pathogenicity genes are spread (Williams \& Hergenrother, 2008). In the process of conjugation, plasmid DNA is transported from a donor to a recipient cell using a mechanism which requires direct contact between the cells (Cascales \& Christie, 2003; Alvarez-Martinez \& Christie, 2009). A multi-protein complex, large enough to span the bacterial cell wall (Llosa et al., 2002), handles the transfer. These plasmid-encoded complexes dedicated to the intercellular transport of proteins or protein-DNA complexes are called type IV secretion systems (T4SS). The T4SS have been studied in detail in Escherichia coli and Agrobacterium tumefaciens, two representatives of Gramnegative bacteria (Llosa et al., 2009; Hayes et al., 2010; de La Cruz et al., 2010; Rêgo et al., 2010; Smillie et al., 2010; Wallden et al., 2010). Most knowledge about Gram-positive T4SS is based on similarity to their Gram-negative counterparts (Grohmann et al., 2003; Abajy et al., 2007). However, much more information regarding proteins involved in the T4S processes is available for bacteria of Gramnegative origin (Grohmann et al., 2003; Kurenbach et al., 2006; Wallden et al., 2010; Clewell, 2011). Only very recently has the first structural information on Gram-positive transfer proteins become available (Porter et al., 2012; Walldén et al., 2012).

pIP501, a multiple antibiotic resistance plasmid, was originally isolated from Streptococcus agalactiae (Horodniceanu et al., 1979). It has the broadest known host range for plasmid transfer in Grampositive bacteria and is furthermore the first conjugative plasmid originating from Gram-positive bacteria for which stable replication in Gram-negative bacteria has been shown (Kurenbach et al., 2003). Fifteen putative transfer proteins are organized in a single operon, the transfer region. Sequence alignments revealed significant similarity of three pIP501 Tra proteins to the T4SS from A. tumefaciens: an ATPase (TraE homologue to VirB4) (Kopec et al., 2005; Abajy et al., 2007), a coupling protein (TraJ homologue to VirD4) (Celic et al., unpublished data) and a lytic transglycosylase (TraG homologue to VirB1) (Arends et al., unpublished data). Another member of the pIP501 transfer operon that has been studied in detail is the relaxase TraA (Kopec et al., 2005; Kurenbach et al., 2006). 


\section{crystallization communications}

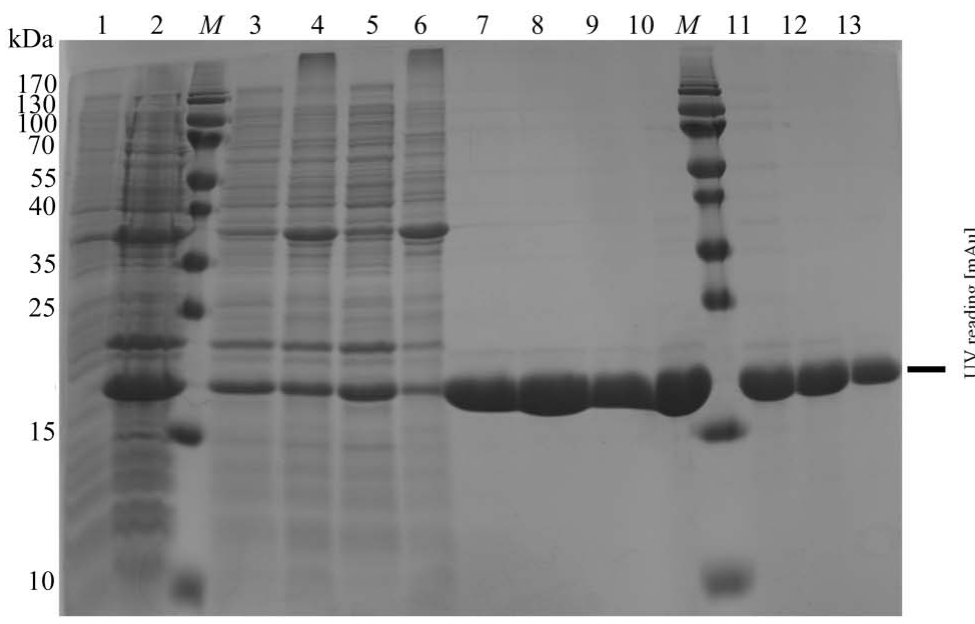

(a)

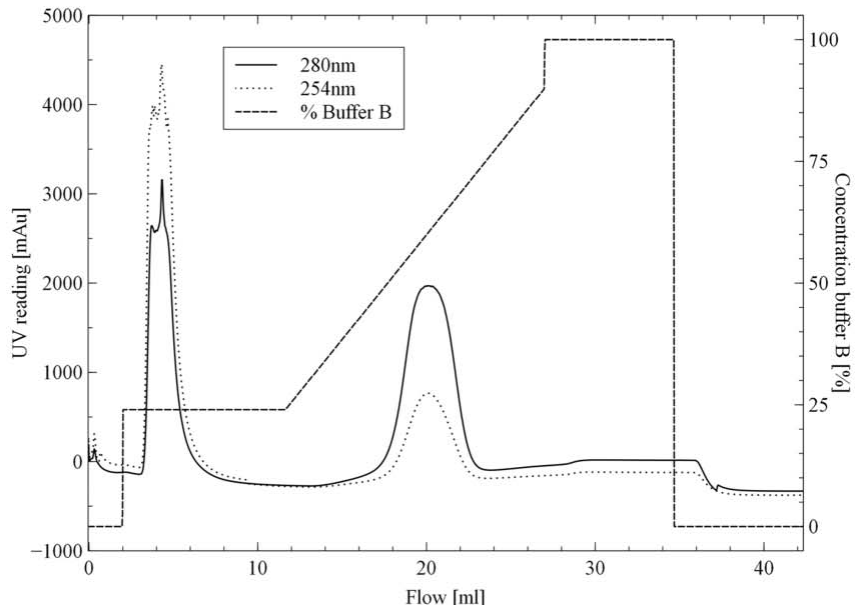

(b)

Figure 1

$\operatorname{TraM} \Delta$ protein production. (a) SDS-PAGE to assess protein production and purification (TraM $\Delta, 18.6 \mathrm{kDa}$ ). Lanes 1 and 2, expression before and after $3 \mathrm{~h}$ IPTG induction; lanes 3 and 5, supernatant of the two-step extraction; lanes 4 and 6, pellet of the two-step extraction; lanes 7-9, main fractions of the His-affinity purification; lane 10, pooled and concentrated His-affinity fractions; lanes 11-13, main size-exclusion chromatography fractions; lane $M$, molecular-mass marker (PageRuler SM0671, Thermo Fisher Scientific, Waltham, Massachusetts, USA; labelled in kDa). (b) His-affinity purification of $\operatorname{TraM} \Delta$. The imidazole gradient is shown as the percentage of buffer $B$ (discontinued line).

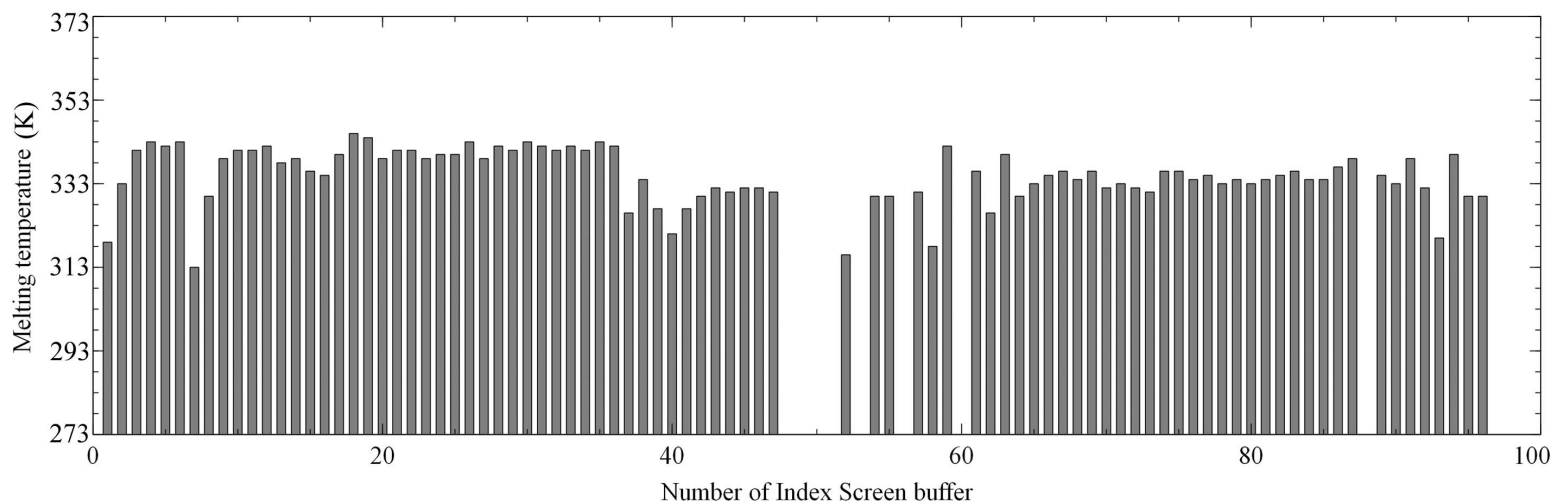

Figure 2

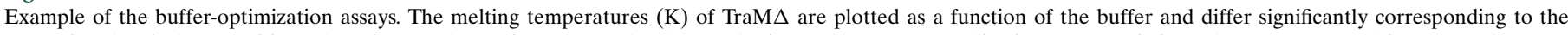

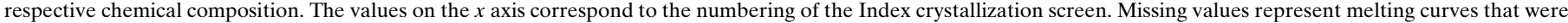
measured but were not interpretable, probably due to precipitation or aggregation of the protein.

Here we present the purification and crystallization of the deletion mutant protein $\operatorname{TraM}_{190-322}$ (formerly called ORF13, GenBank: CAD44393.1; $\operatorname{TraM}_{190-322}$ - further referred to as $\operatorname{TraM} \Delta$ ), an $18.6 \mathrm{kDa}$ protein of the T4SS encoded by the conjugative plasmid pIP501. TraM $\Delta$ is the first transfer protein of this system to be crystallized. Analytical gel filtration, dynamic light scattering (DLS) and small-angle X-ray scattering (SAXS) show a monomer in solution under the tested conditions. So far, no protein-protein interactions of TraM with other pIP501 transfer proteins have been detected (Abajy et al., 2007) and no relations were found on the sequence level either. As the protein localizes to the cell membrane (Goessweiner-Mohr et al., 2012), we suggest a role in the scaffolding of the pIP501 core complex.

\section{Protein purification}

As the full-length protein was insoluble, the putative N-terminal domain and a central trans-membrane motif of TraM were deleted and a soluble construct was generated. In brief, $\operatorname{tra} M \Delta$ was cloned into the $7 \times$ His-tag expression vector pQTEV (a gift from K. Büssow, Max-Planck-Institute for Molecular Genetics, Berlin, Germany) and E. coli BL21-CodonPlus (DE3)-RIL (Stratagene, Amsterdam, The Netherlands) competent cells were transformed with the recombinant construct, pQTEV-traM $\Delta$. For the selenomethionine expression, pQTEV-traM $\Delta$ plasmid DNA was isolated and transformed into the methionine-deficient E. coli strain B834 (DE3) (Merck, Darmstadt, Germany) using standard protocols.

Large-scale expression of TraM $\Delta$ was performed in $500 \mathrm{ml} \mathrm{LB}$ medium, supplemented with $100 \mu \mathrm{g} \mathrm{ml}^{-1}$ ampicillin. At an $\mathrm{OD}_{600}$ of $\sim 0.6$ expression was induced by the addition of $1 \mathrm{~m} M$ IPTG. After $3 \mathrm{~h}$ at $310 \mathrm{~K}$, cells were harvested and immediately frozen at $253 \mathrm{~K}$. TraM $\Delta$ expression levels were monitored by SDS-PAGE (Fig. 1a).

For the expression of the selenomethionine derivative, un-induced cells were harvested at an $\mathrm{OD}_{600}$ of $\sim 0.6$, resuspended in $\mathrm{M} 9$ minimal medium and growth was continued for an additional hour at $310 \mathrm{~K}$. The cells were induced with $119 \mathrm{mg}$ IPTG, $25 \mathrm{mg}$ of selenomethionine were added and overexpression continued for $3 \mathrm{~h}$. In all preparations, 


\section{crystallization communications}

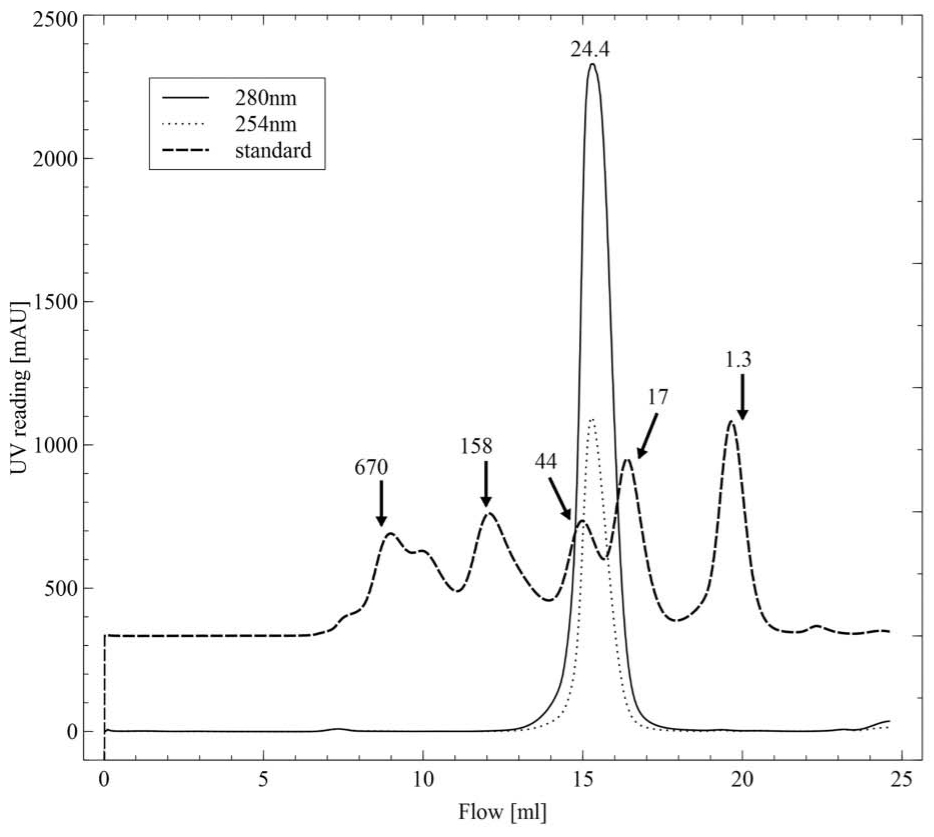

(a)

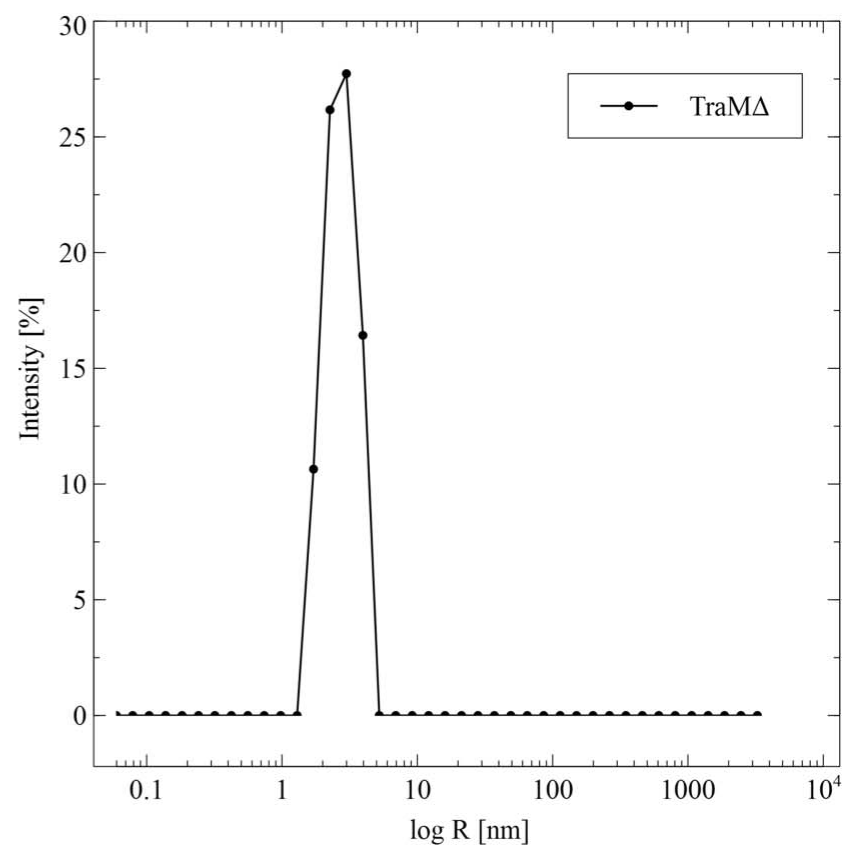

(b)

Figure 3

Biophysical characterization of $\operatorname{TraM} \Delta$. (a) TraM $\Delta$ elutes as a single peak from the Superdex 200 size-exclusion column. The $280 \mathrm{~nm}$ (solid line) and $254 \mathrm{~nm}$ (dotted line) readings are shown. A standard (BioRad) is shown with its molecular weight (discontinued). (b) In the monodispersity analysis via DLS TraM $\Delta$ appears as a narrow peak.

$500 \mathrm{ml}$ of LB media were used. The cells were harvested and immediately frozen at $253 \mathrm{~K}$.

For the purification of the seleno-TraM $\Delta$ the cells were resuspended in $40 \mathrm{ml} 25 \mathrm{~m} M$ HEPES $\mathrm{pH}$ 7.6, $75 \mathrm{~m} M$ ammonium sulfate. $2 \mu \mathrm{l}$ DNAse I (Sigma-Aldrich, St Louis, USA), $1 \mathrm{~m} M$ phenylmethanesulfonyl fluoride (PMSF) and $2 \mathrm{~m} M$ benzamidine were added, the solution was vigorously mixed (UltraTurrax, IKA, Staufen, Germany) and kept on ice for $30 \mathrm{~min}$. The solution was sonicated (Sonopuls HD2070, Bandelin; 1 min, continuous sonification, $\sim 80 \%$ amplitude) and centrifuged for $30 \mathrm{~min}$ at $281 \mathrm{~K}$ and $15000 g$. Pellet and supernatant fractions were analysed by SDSPAGE (Fig. 1a). The pellet was applied to a second extraction step with $20 \mathrm{ml}$ of the buffer mentioned above, but without additives. $\operatorname{TraM} \Delta$-containing supernatants were pooled and loaded onto a HisTrap FF 1 ml column (GE Healthcare, Chalfont St Giles, UK) for affinity purification (Fig. $1 b$ ). The purity of $\operatorname{TraM} \Delta$ was assessed by SDS-PAGE (Fig. 1a). Imidazole was removed by buffer exchange during concentrating (Amicon tubes, 3000 MWCO, Merck Millipore, Darmstadt, Germany).

Purified $\operatorname{TraM} \Delta$ protein with a concentration of $1 \mathrm{mg} \mathrm{ml}^{-1}$ was applied to an adapted Thermofluor buffer optimization screen (Ericsson et al., 2006) using the conditions of various commercial crystallization screens: Index and Crystal Screen and Crystal Screen 2 (Hampton Research, Aliso Viejo, California, USA), as well as Morpheus and JCSG (Molecular Dimensions, Newmarket, Suffolk, UK). For the screen, $10 \mu \mathrm{l}$ of protein sample were mixed with $10 \mu \mathrm{l}$ of the respective buffer and $5 \mu \mathrm{l}$ of $50 \times$ SYPRO Orange (SigmaAldrich, St Louis, USA). The resulting thermostability curves were analysed (see Fig. 2 as an example), an optimized extraction buffer was designed, combining the buffer components (Collins et al., 2004) which showed a thermostabilizing effect, while keeping the composition as simple as possible. This buffer consisted of $50 \mathrm{~m} M$ HEPES $\mathrm{pH}$ 7.0, $200 \mathrm{~m} M$ ammonium sulfate and was used for all subsequent $\operatorname{TraM} \Delta$ extractions, as well as for crystallization.

\section{Biophysical characterization}

For the biophysical characterization, TraM $\Delta$ was extracted and Hisaffinity purified in $50 \mathrm{~m} M$ Tris $\mathrm{pH} 7.45,200 \mathrm{~m} M$ ammonium sulfate. $\operatorname{TraM} \Delta$-containing His-affinity fractions were pooled and concentrated to a concentration of $2.2 \mathrm{mg} \mathrm{ml}^{-1}$ via centrifugation in Amicon tubes (3000 MWCO). TraM $\Delta$ was further purified by size-exclusion chromatography with a Superdex 200 HR 10/30 column (GE Healthcare). A gel-filtration standard (BioRad, Hercules California, USA; $670 / 158 / 44 / 17 / 1.35 \mathrm{kDa}$ ) was used to calculate the molecular weight of $\operatorname{TraM} \Delta$. TraM $\Delta$ eluted from the gel-filtration column as a single peak (Fig. $3 a$ ), indicative of a homogeneous species with an apparent molecular weight of $24.4 \mathrm{kDa}$. This value compares to the theoretical molecular weight of the His-tagged construct of $18.6 \mathrm{kDa}$, suggesting that $\operatorname{TraM} \Delta$ is a monomer in solution.

The mono-dispersity of TraM $\Delta$ was evaluated by DLS. For the DLS measurements, a size-exclusion fraction, containing $0.9 \mathrm{mg} \mathrm{ml}^{-1}$ $\operatorname{TraM} \Delta$, was measured directly in a $45 \mu \mathrm{l}$ cuvette. Ten measurements with constant baseline were merged, yielding a single peak with a calculated polydispersity of $26.7 \%$ and a hydrodynamic $\left(R_{\mathrm{h}}\right)$ radius of $2.8 \mathrm{~nm}$ (Fig. 3c).

Circular dichroism (CD) measurements were performed on a Jasco J715 (JASCO Inst., Gross-Umstadt, Germany) spectro-polarimeter equipped with an external thermostat. Spectra were measured from 260 to $190 \mathrm{~nm}$ in a $0.01 \mathrm{~cm}$ cuvette and with a protein concentration of $0.9 \mathrm{mg} \mathrm{ml}^{-1}$. Ten individual spectra were accumulated and the standard deviation was calculated from the repeated measurements. Temperature scans were performed in a $0.02 \mathrm{~cm}$ temperaturecontrolled cuvette in the range from 298 to $368 \mathrm{~K}$ using a step-scan procedure with a constant wavelength of $208 \mathrm{~nm}$. Spectra resulted from three accumulated scans, which were measured from 260 to $190 \mathrm{~nm}$ every $5 \mathrm{~K}$. The temperature gradient was set to $1 \mathrm{~K} \mathrm{~min}^{-1}$. $\operatorname{TraM} \Delta$ was applied at a concentration of $0.45 \mathrm{mg} \mathrm{ml}^{-1}$. The $\mathrm{CD}$ data were evaluated using the online service Dichroweb (Whitmore \& 


\section{crystallization communications}

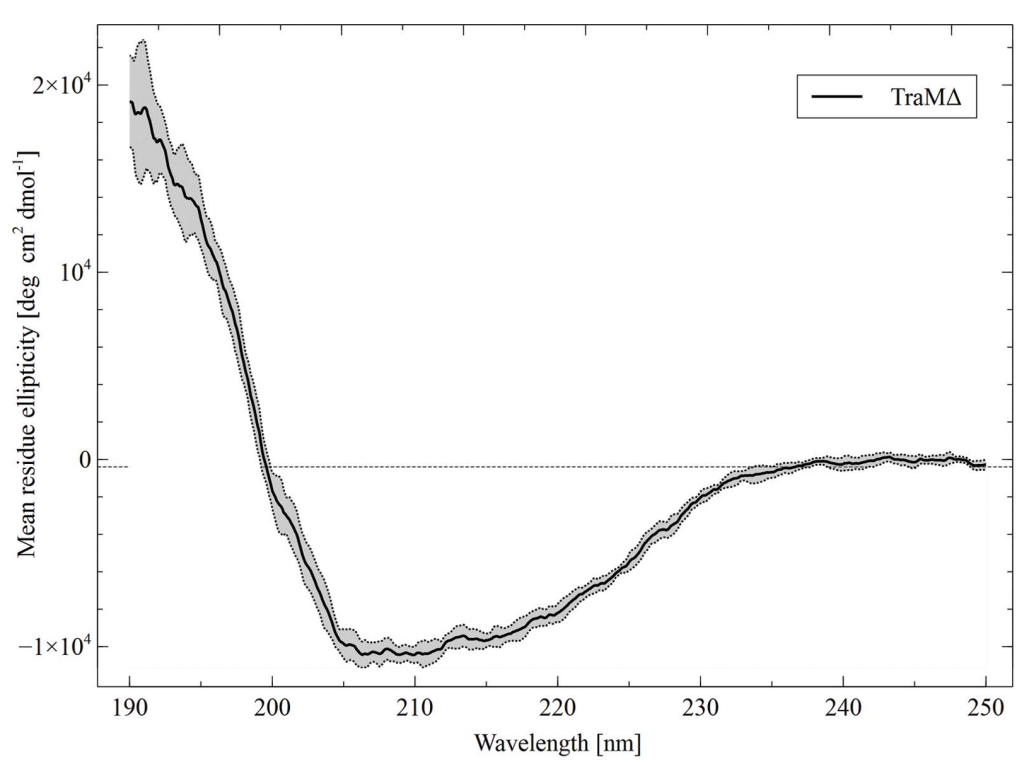

\begin{tabular}{|c|c|}
\hline Secondary structure & Amount [\%] \\
\hline Alpha helices & 14 \\
\hline Beta strands & 33 \\
\hline Turns & 23 \\
\hline Unordered & 30 \\
\hline
\end{tabular}

(b)

(a)
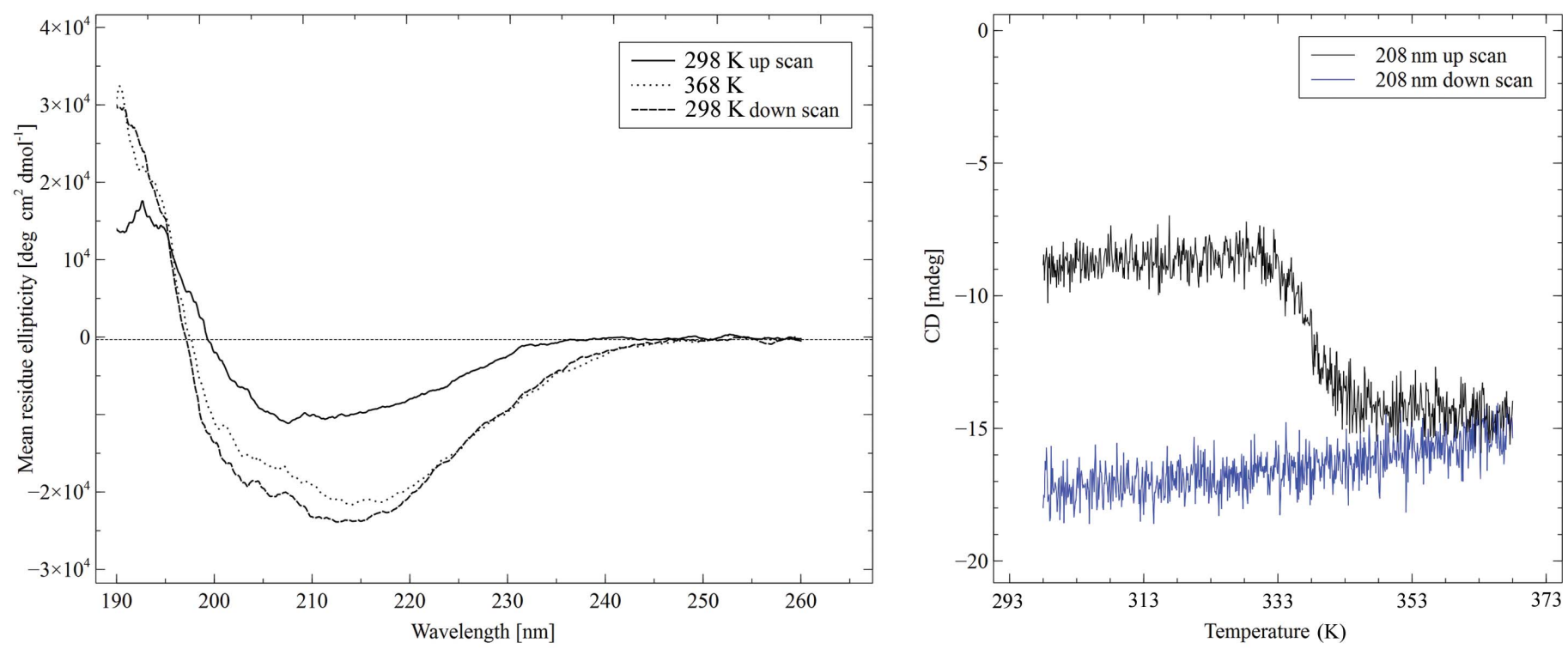

(c)

Figure 4

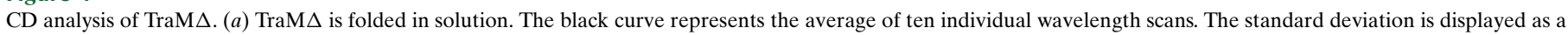

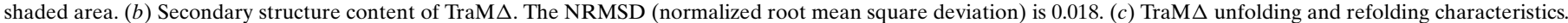
The CD spectra are shown at 298 and $368 \mathrm{~K}$ and after cooling to $298 \mathrm{~K}$ (left panel). The temperature scan at $208 \mathrm{~nm}$ (up- and down-scan) is shown in the right panel.

Wallace, 2008) with reference database No. 4. Purified TraM $\Delta$ is folded in solution and has a mixed $\alpha-\beta$ composition (Fig. $4 a$ ). The amount of $\beta$-sheets exceeds that of $\alpha$-helices by more than two times (Fig. $4 b$ ). The large proportion of unordered structure (30\%) may result from flexible $\mathrm{N}$ - or $\mathrm{C}$-terminal parts. Temperature scans revealed that $\operatorname{TraM} \Delta$ undergoes a transition at $338 \mathrm{~K}$ (Fig. $4 c$ ), but does not unfold completely even at $368 \mathrm{~K}$. Instead the CD spectrum at $368 \mathrm{~K}$ shows the characteristics of a protein with increased $\beta$-sheet contents. As the protein is trapped in this state (i.e. no refolding during the down-scan), we call the state of $\operatorname{TraM} \Delta$ upon heating ' $\beta$ arrest'.

SAXS measurements were performed to gain more information about the oligomeric state and shape of $\operatorname{TraM} \Delta$ in solution. For the measurements on the X33 beamline (DESY, Hamburg, Germany), TraM $\Delta$ was suspended in $100 \mathrm{~m} M$ ammonium sulfate, $100 \mathrm{mM} \mathrm{NaCl}$,
$50 \mathrm{~m} M$ HEPES pH 7.0. Size-exclusion purified protein was concentrated to a final concentration of $2.8 \mathrm{mg} \mathrm{ml}^{-1}$. TraM $\Delta$ was measured at three different concentrations: $2.65 / 1.25 / 0.65 \mathrm{mg} \mathrm{ml}^{-1}$. The program PRIMUS (Konarev et al., 2003) was used for data analysis, yielding an $I_{0}$ of 19.46 , a radius of gyration $\left(R_{\mathrm{g}}\right)$ of $2.5 \mathrm{~nm}$ and a $D_{\max }$ of $8 \mathrm{~nm}$, as calculated from the Guinier plot (data at $1.25 \mathrm{mg} \mathrm{ml}^{-1}$ ) and the $p(r)$ function, respectively. The radius of gyration is in good agreement with the hydrodynamic radius $(2.8 \mathrm{~nm})$ determined by DLS measurements. From $I_{0}$ we calculated the apparent molecular weight of TraM $\Delta$ in solution, using BSA (bovine serum albumin) as a molecular-weight standard (Pavkov et al., 2008). The value of $20.1 \mathrm{kDa}$ is in good agreement with the theoretical molecular weight of $\operatorname{TraM} \Delta(18.6 \mathrm{kDa})$ and with the observation from gel filtration $(24.4 \mathrm{kDa})$. Calculating ab initio models from the scattering function, we observed an elongated particle, which may be due to the 


\section{crystallization communications}

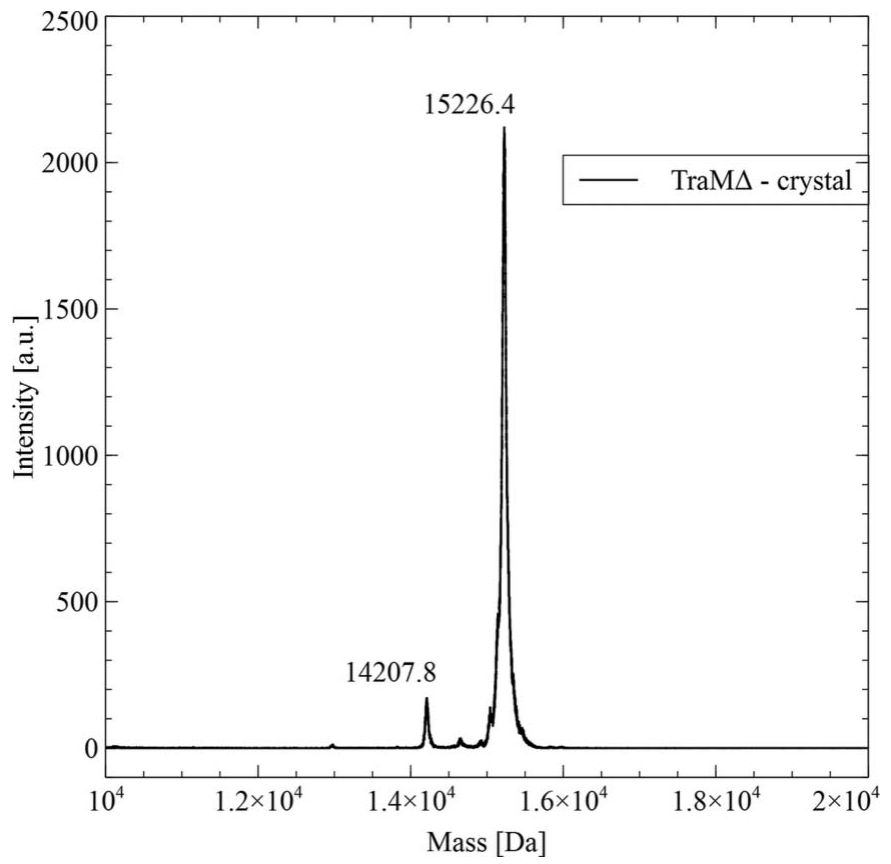

Figure 5

MALDI-TOF analysis of $\operatorname{TraM} \Delta$ crystals.

flexible $\mathrm{N}$-terminal end of $\operatorname{TraM} \Delta$, containing the unstructured $7 \times$ His tag.

\section{Crystallization}

All crystallization experiments were performed with an Oryx8 robot (Douglas Instruments, East Garston, Hungerford, Berkshire, UK) using the microbatch method (Chayen et al., 1992). The following screens were used: Index, Crystal Screen and Crystal Screen 2, PEG/ Ion (Hampton Research) and JCSG, Morpheus (Molecular Dimensions). The protein concentrations used were between 4 and $6 \mathrm{mg} \mathrm{ml}^{-1}$ and the drop ratio was 1:1 with a total drop volume of $1 \mu \mathrm{l}$. All plates were covered with paraffin oil $(\sim 4 \mathrm{ml})$ and stored at $293 \mathrm{~K}$. Protein crystals were tested for diffraction on a rotating-anode diffractometer (MicroStar, Bruker AXS, Madison, Wisconsin, USA).
The only positive candidate condition [Index No. 44: $0.1 M$ HEPES $\mathrm{pH} 7.5,25 \%(w / v)$ PEG 3350] was used for microbatch $\mathrm{pH} / \mathrm{PEG}$ optimization with constant protein drop ratios of 35 and $50 \%(\mathrm{v} / \mathrm{v})$. The protein concentration was lowered further, to facilitate slower crystal growth. Since there are no protein structures with significant sequence similarity to $\operatorname{TraM} \Delta$ available, molecular replacement was not an option for structure solution. Thus, all optimizations were performed with the selenomethionine derivative of $\operatorname{TraM} \Delta$, leading to the final conditions: protein stock $3.0 \mathrm{mg} \mathrm{ml}^{-1}$; drop volume $2 \mu \mathrm{l}$ (0.7 $\mu$ l protein solution, $1.3 \mu$ precipitant solution ); $0.1 M$ HEPES $\mathrm{pH}$ 7.33, PEG $335016.5 \%(v / v)$.

To confirm the integrity of $\operatorname{TraM} \Delta$ in the crystals, we analysed dissolved crystals via mass spectroscopy (MS). Several crystals of $\operatorname{TraM} \Delta$ were dissolved in $10 \mu \mathrm{l}$ of pure $\mathrm{H}_{2} \mathrm{O}$ and investigated by matrix-assisted laser desorption/ionization-time-of-flight (MALDITOF) analysis (Bruker, ultrafleXtreme, Vienna, Austria). This experiment showed that the protein present in the crystals (Fig. 5; $15.2 \mathrm{kDa}$ ) was significantly smaller than the original His-tagged construct $(18.6 \mathrm{kDa})$, with the $3.4 \mathrm{kDa}$ difference representing approximately 30 residues. These residues were lost due to unintended in situ proteolytic activity during the crystallization. Subsequently, one of the samples was digested with trypsin and further analysed via MS/MS, yielding the N-terminal sequence 'SVKKESEL' and a sequence coverage of 130 residues (193 to 322 of the original TraM sequence), resulting in a theoretical molecular mass of $15232 \mathrm{Da}$.

\section{Data collection and processing}

Crystals were flash-cooled without cryoprotectant (Fig. 6a). Data collection was performed at $100 \mathrm{~K}$ on the synchrotron beamline X06DA at SLS, Villigen, Switzerland. Most of the tested selenomethionine-containing crystals diffracted to a limited resolution (weak spots to less than $7 \AA$ resolution in the best direction) on our home source and at the synchrotron. A single crystal showed diffraction with clear spots and a non-twinned pattern at better than $2.5 \AA$ resolution at the SLS (Fig. 6b). A fluorescence scan was performed to validate the presence of selenomethionine in the crystal and to define the optimal setup for anomalous data collection at the seleno $f^{\prime \prime}$ peak wavelength $(0.9792 \AA)$. A crystal-to-detector distance

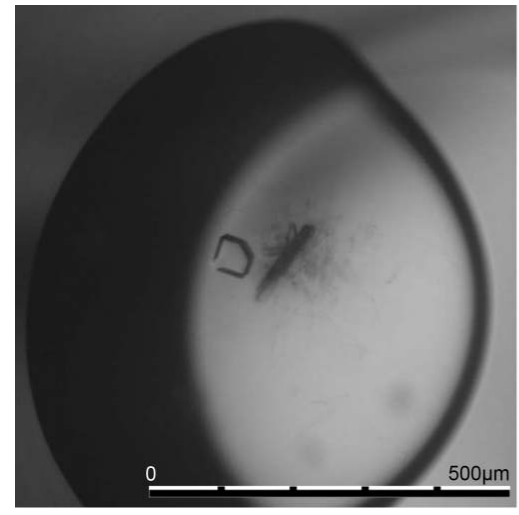

(a)

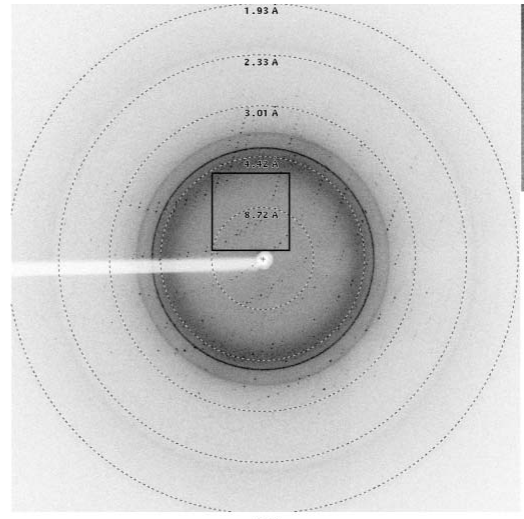

(b)

Figure 6

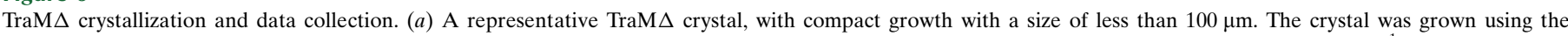

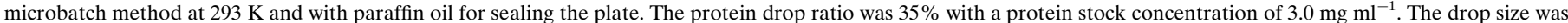

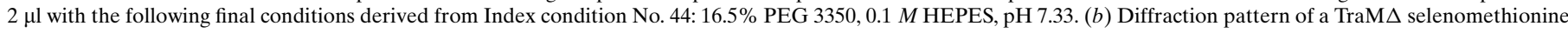

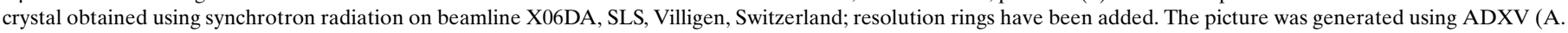
Arvail). Inset, detail of the diffraction shown in $(b)$. 
Table 1

Data-collection and processing statistics of scaled data.

Values in parentheses are for the highest-resolution shell.

\begin{tabular}{ll}
\hline Beamline & X06DA (PXIII), SLS, Villigen, Switzerland \\
Space group & $P 1$ \\
Detector & MAR CCD \\
Unit-cell dimensions $\left(\AA,^{\circ}\right)$ & $a=39.21, b=54.98, c=93.47$, \\
& \multicolumn{1}{c}{$\alpha=89.91, \beta=86.44, \gamma=78.63$} \\
Wavelength $(\AA)$ & 0.9792 \\
Resolution range $(\AA)$ & $50-2.5(2.6-2.5)$ \\
$R_{\text {meas }} \dagger(\%)$ & $12.8(53.1)$ \\
$\langle I / \sigma(I)\rangle$ & $14.91(4.05)$ \\
No. of molecules in asymmetric unit & 6 \\
Matthews coefficient $\left(\AA^{3} \mathrm{Da}^{-1}\right)$ & 2.16 \\
Solvent content $(\%)$ & 43.04 \\
Unique reflections & $51575(5801)$ \\
Measured reflections & $293455(31927)$ \\
Redundancy & $5.7(5.5)$ \\
Completeness $(\%)$ & $97.5(97.7)$ \\
\hline
\end{tabular}

$\dagger R_{\text {meas }}=\sum_{h k l}\{N(h k l) /[N(h k l)-1]\}^{1 / 2} \sum_{i}\left|I_{i}(h k l)-\langle I(h k l)\rangle\right| / \sum_{h k l} \sum_{i} I_{i}(h k l)$.

Table 2

Results for the Matthews coefficient calculation.

Values calculated for a molecular weight of $15226 \mathrm{Da} . \mathrm{Nmol} / \mathrm{asym}=$ no. of molecules in asymmetric unit.

\begin{tabular}{lllll}
\hline Nmol/asym & $\begin{array}{l}\text { Matthews } \\
\text { coefficient }\end{array}$ & $\begin{array}{l}\text { Solvent } \\
(\%)\end{array}$ & $\begin{array}{l}\text { Probability }(N) \\
\text { for given resolution } \\
(2.5 \AA)\end{array}$ & $\begin{array}{l}\text { Probability }(N) \\
\text { overall }\end{array}$ \\
\hline 1 & 12.95 & 90.51 & 0 & 0 \\
2 & 6.47 & 81.01 & 0 & 0 \\
3 & 4.32 & 71.52 & 0.01 & 0.01 \\
4 & 3.24 & 62.03 & 0.10 & 0.11 \\
5 & 2.59 & 52.53 & 0.40 & 0.39 \\
6 & 2.16 & 43.04 & 0.43 & 0.43 \\
7 & 1.85 & 33.55 & 0.05 & 0.05 \\
8 & 1.62 & 24.05 & 0 & 0 \\
9 & 1.44 & 14.56 & 0 & 0 \\
10 & 1.29 & 5.07 & 0 & \\
\hline
\end{tabular}

of $200 \mathrm{~mm}$, an oscillation range of $1.0^{\circ}$ and an exposure time of $1 \mathrm{~s}$ per image were chosen. Three individual data sets were collected at different spots on the same crystal and later scaled together.

The crystals belonged to space group $P 1$, with unit-cell parameters $a=39.21, b=54.98, c=93.47 \AA, \alpha=89.91, \beta=86.44, \gamma=78.63^{\circ}$ and six molecules per asymmetric unit. The Matthews coefficient (Matthews, 1968; Kantardjieff \& Rupp, 2003) was calculated as $2.16 \AA^{3} \mathrm{Da}^{-1}$, with a solvent content of $43.04 \%$ (Tables 1 and 2). In order to determine the internal symmetry we performed a self-rotation function (Tollin \& Rossmann, 1966) yielding a strong threefold axis and three perpendicular twofold axes, which indicates six molecules in the asymmetric unit.

The data sets were processed and scaled together using the programs XDS and XSCALE (Kabsch, 2010). The programs AutoSol (McCoy et al., 2007; Terwilliger et al., 2009) and AutoBuild (Terwilliger et al., 2008) of the PHENIX software suite (Adams et al., 2010) were used to define the seleno heavy-atom sites and to build a first model. The generated electron-density map, including the Hendrickson-Lattman coefficients and heavy-atom coordinates, was put in BUCCANEER (Cowtan, 2006). The resulting model was completed manually and is currently being refined. The final $\operatorname{TraM} \Delta$ structure has been published (Goessweiner-Mohr et al., 2012).

This work was supported by the Austrian Science Fund (FWF) project Nos. P19794-B12 and F4604. Staff support during data collection at the SLS synchrotron X06DA beamline is gratefully acknowledged. TP-K was supported by the Federal Ministry of
Economy, Family and Youth (BMWFJ), the Federal Ministry of Traffic, Innovation and Technology (bmvit), the Styrian Business Promotion Agency SFG, the Standortagentur Tirol and ZIT Technology Agency of the City of Vienna through the COMET Funding Program managed by the Austrian Research Promotion Agency FFG.

\section{References}

Abajy, M. Y., Kopeć, J., Schiwon, K., Burzynski, M., Döring, M., Bohn, C. \& Grohmann, E. (2007). J. Bacteriol. 189, 2487-2496.

Adams, P. D. et al. (2010). Acta Cryst. D66, 213-221.

Alvarez-Martinez, C. E. \& Christie, P. J. (2009). Microbiol. Mol. Biol. Rev. 73, 775-808.

Cascales, E. \& Christie, P. J. (2003). Nature Rev. Microbiol. 1, 137-149.

Chayen, N. E., Shaw Stewart, P. D. \& Blow, D. M. (1992). J. Cryst. Growth, 122, 176-180.

Clewell, D. B. (2011). Mob. Genet. Elements, 1, 38-54.

Collins, B. K., Tomanicek, S. J., Lyamicheva, N., Kaiser, M. W. \& Mueser, T. C. (2004). Acta Cryst. D60, 1674-1678.

Cowtan, K. (2006). Acta Cryst. D62, 1002-1011.

de la Cruz, F., Frost, L. S., Meyer, R. J. \& Zechner, E. L. (2010). FEMS Microbiol. Rev. 34, 18-40.

Ericsson, U. B., Hallberg, B. M., Detitta, G. T., Dekker, N. \& Nordlund, P. (2006). Anal. Biochem. 357, 289-298.

Goessweiner-Mohr, N., Grumet, L., Arends, K., Pavkov-Keller, T., Gruber, C. C., Gruber, K., Birner-Gruenberger, R., Kropec-Huebner, A., Huebner, J., Grohmann, E. \& Keller, W. (2012). J. Biol. Chem. 288, 2018-2028.

Grohmann, E., Muth, G. \& Espinosa, M. (2003). Microbiol. Mol. Biol. Rev. 67, 277-301.

Hayes, C. S., Aoki, S. K. \& Low, D. A. (2010). Annu. Rev. Genet. 44, 71-90.

Horodniceanu, T., Bougueleret, L., El-Solh, N., Bouanchaud, D. H. \& Chabbert, Y. A. (1979). Plasmid, 2, 197-206.

Kabsch, W. (2010). Acta Cryst. D66, 125-132.

Kantardjieff, K. A. \& Rupp, B. (2003). Protein Sci. 12, 1865-1871.

Konarev, P. V., Volkov, V. V., Sokolova, A. V., Koch, M. H. J. \& Svergun, D. I. (2003). J. Appl. Cryst. 36, 1277-1282.

Kopec, J., Bergmann, A., Fritz, G., Grohmann, E. \& Keller, W. (2005). Biochem. J. 387, 401-409.

Kurenbach, B., Bohn, C., Prabhu, J., Abudukerim, M., Szewzyk, U. \& Grohmann, E. (2003). Plasmid, 50, 86-93.

Kurenbach, B., Kopeć, J., Mägdefrau, M., Andreas, K., Keller, W., Bohn, C., Abajy, M. Y. \& Grohmann, E. (2006). Microbiology, 152, 637-645.

Llosa, M., Gomis-Rüth, F. X., Collect, M. \& de la Cruz Fd, F. (2002). Mol. Microbiol. 45, 1-8.

Llosa, M., Roy, C. \& Dehio, C. (2009). Mol. Microbiol. 73, 141-151.

McCoy, A. J., Grosse-Kunstleve, R. W., Adams, P. D., Winn, M. D., Storoni, L. C. \& Read, R. J. (2007). J. Appl. Cryst. 40, 658-674.

Matthews, B. W. (1968). J. Mol. Biol. 33, 491-497.

Pavkov, T., Egelseer, E. M., Tesarz, M., Svergun, D. I., Sleytr, U. B. \& Keller, W. (2008). Structure, 16, 1226-1237.

Porter, C. J., Bantwal, R., Bannam, T. L., Rosado, C. J., Pearce, M. C., Adams, V., Lyras, D., Whisstock, J. C. \& Rood, J. I. (2012). Mol. Microbiol. 83, 275288.

Rêgo, A. T., Chandran, V. \& Waksman, G. (2010). Biochem. J. 425, 475-488.

Smillie, C., Garcillán-Barcia, M. P., Francia, M. V., Rocha, E. P. \& de la Cruz, F. (2010). Microbiol. Mol. Biol. Rev. 74, 434-452.

Terwilliger, T. C., Adams, P. D., Read, R. J., McCoy, A. J., Moriarty, N. W. Grosse-Kunstleve, R. W., Afonine, P. V., Zwart, P. H. \& Hung, L.-W. (2009). Acta Cryst. D65, 582-601.

Terwilliger, T. C., Grosse-Kunstleve, R. W., Afonine, P. V., Moriarty, N. W., Zwart, P. H., Hung, L.-W., Read, R. J. \& Adams, P. D. (2008). Acta Cryst. D64, 61-69.

Tollin, P. \& Rossmann, M. G. (1966). Acta Cryst. 21, 872-876.

Wallden, K., Rivera-Calzada, A. \& Waksman, G. (2010). Cell. Microbiol. 12, 1203-1212.

Walldén, K., Williams, R., Yan, J., Lian, P. W., Wang, L., Thalassinos, K., Orlova, E. V. \& Waksman, G. (2012). Proc. Natl Acad. Sci. USA, 109, 1134811353.

Whitmore, L. \& Wallace, B. A. (2008). Biopolymers, 89, 392-400.

Williams, J. J. \& Hergenrother, P. J. (2008). Curr. Opin. Chem. Biol. 12, 389 399. 